\title{
Glucagon Secretion in Diabetic Patients with Idiopathic Haemochromatosis
}

\author{
P. Passa ${ }^{1}$, A.S. Luyckx ${ }^{2}$, J. L. Carpentier ${ }^{2}$, P. J. Lefebvre ${ }^{2}$, and J. Canivet ${ }^{1}$ \\ ${ }^{1}$ Department of Metabolism and Endocrinology, Hôpital Saint Louis, University of Paris VII, Paris, France, and ${ }^{2}$ Division of Diabetes, \\ Institute of Medicine, University of Liège, Liège, Belgium
}

Summary. The aim of the present investigation was to determine in patients with idiopathic haemochromatosis whether diabetes is of the primary type or secondary to pancreatic injury due to iron deposition. For this purpose, plasma glucagon concentrations were determined following arginine infusion or an oral glucose load in eight patients with diabetes and idiopathic haemochromatosis. The enhanced glucagon response to arginine and the nonsuppressibility of glucagon secretion by oral glucose found in these patients were similar to the results found in the same tests performed in our previous series of patients with "idiopathic" diabetes and at variance with those reported by others in patients with chronic pancreatitis.

Key words: Idiopathic haemochromatosis, diabetes, glucagon secretion, arginine infusion, oral glucose tolerance test.

Diabetes is common in the course of idiopathic haemochromatosis (I. H.). It has long been stated that glucose intolerance in patients with $\mathrm{I} . \mathrm{H}$. is due to the pancreatic lesions resulting from the pancreatic iron overload; therefore diabetes is usually considered as secondary to pancreatic pathology [1-4]. However some recent data suggest that pancreas iron overload is not the main cause of glucose intolerance, that diabetes may be regarded as related to the inherited type and that iron overload may only favour its onset [5-7].

It has been shown that glucagon secretion is increased in idiopathic diabetes $[8,9]$ and reduced in chronic pancreatitis [10-12] and after pancreatectomy in the human $[13,14]$; the determination of al- pha cell function may thus provide a useful means of distinguishing idiopathic diabetes from the glucose intolerance resulting from acquired pancreatic injury [12]. It has also been shown that no reduction in plasma glucagon level occurs in hyperglycaemia following an oral glucose load in idiopathic diabetes [15], while a decreased plasma glucagon response following insulin hypoglycaemia is observed in subjects with chronic pancreatitis [16]. The aim of this study was therefore to determine the plasma glucagon response to IV arginine and an oral glucose load in diabetic patients with I. H.

\section{Material and Methods}

\section{A) Patients}

Eight male diabetic patients with I.H., of average age $53 \pm 4$ years and mean weight $103 \pm 4 \%$ of ideal body weight (mean \pm SEM), were selected. Clinical features are recorded in Table 1.

The diagnosis of I. H. was based on: 1) clinical manifestations including hyperpigmentation, liver enlargement and diabetes; 2) raised serum iron level over $190 \mu \mathrm{g} / 100 \mathrm{ml}$ with over $80 \%$ saturation of serum total iron-binding capacity; 3) evidence of iron overload estimated in liver biopsy specimens, 4) positive data for haemochromatosis among family members, or absence of any possible non-familial origin of iron overload, that is severe alcoholism, haematological abnormalities or anaemia even after long-term phlebotomy. In this selection, patients for whom the diagnosis of I.H. was doubtful and patients with normal glucose tolerance were discarded.

These patients were treated by phlebotomy, but they still had heavy iron overload at the time of the study. One of them (case $n^{\circ} 6$ ) also had radiological 
Table 1. Clinical features

\begin{tabular}{lcccll}
\hline Subjects & Sex & $\begin{array}{l}\text { Age } \\
\text { (yrs) }\end{array}$ & $\begin{array}{l}\text { Weight } \\
\text { in } \% \\
\text { of I. B. W. }\end{array}$ & $\begin{array}{l}\text { Clinical } \\
\text { duration } \\
\text { of diabetes } \\
\text { (yrs) }\end{array}$ & $\begin{array}{l}\text { Treatment of } \\
\text { diabetes }\end{array}$ \\
\hline 1 & & & & & \\
2 & M & 49 & 103 & 8 & Insulin \\
3 & M & 44 & 104 & 9 & Insulin \\
4 & M & 38 & 103 & 2 & Insulin \\
5 & M & 68 & 130 & 14 & Insulin \\
6 & M & 55 & 101 & 15 & Metformin \\
7 & M & 62 & 96 & 24 & Insulin \\
8 & M & 60 & 106 & 14 & Chlorpropamide \\
Mean & M & 52 & 91 & 1 & Diet \\
\hline
\end{tabular}

a I.B.W.: According to Metropolitan Life Insurance Tables 1959

evidence of pancreatic calcification. None of them had recently recovered from hypoglycaemia or from ketonuria. Informed consent was obtained from all of them for the procedures carried out in this study.

\section{B) Methods}

Tests were performed in the morning at 8 a.m., after twelve hours resting and fasting. Oral hypoglycaemic drugs were withdrawn twenty-four hours before the test; long acting insulin (Novo lente zinc insulin) was withdrawn twenty-four hours before the test and intermediate-acting insulin (Rapitard Novo insulin) was withdrawn twelve hours before the test.

Arginine stimulation test was carried out as follows: after a twenty minute control period, 1-arginine monochloride $(100 \mathrm{~g} / \mathrm{l})$ was infused at a steady rate $(11.7 \mathrm{mg} / \mathrm{kg} / \mathrm{min})$ for forty minutes using an Infusomat pump (Braun Melsungen). Blood samples were taken from an antecubital vein through a Teflon catheter at $-20,-10,0,5,10,20,30,40,55$, 70 and 90 minutes, time 0 corresponding to the beginning of the infusion.

The oral glucose tolerance test was carried out using a $100 \mathrm{~g}$ glucose load dissolved in $400 \mathrm{ml}$ of water. Blood samples were taken fasting and at intervals of thirty minutes for five hours after ingesting the load.

\section{C) Determinations}

Blood glucose was determined by the orthotoluidine method [17] adapted to the Technicon Auto Analyser, and non esterified fatty acids (NEFA) by the microtitrimetric method of Dole and Meinertz [18]. Glucagon was measured by a specific radioimmunoassay procedure developed by Luyckx [19] using 30 $\mathrm{K}$ anti-serum kindly provided by $\mathrm{Dr}$. Unger. All determinations were made in duplicate.
Liver function was evaluated by prothrombintest, total bilirubin, total protein, albumin, alkaline phosphatase, serum glutamic oxaloacetic transaminase and the bromsulphtalein test, and kidney function by plasma creatinine level, using conventional methods.

\section{Results}

Results of the arginine stimulation test are shown in Figure 1. Fasting blood glucose level was $137 \pm 17$ $\mathrm{mg} / 100 \mathrm{ml}$ (mean of the three preinfusion determinations) and increased slowly, reaching its maximum value fifteen minutes after the end of the infusion. The mean basal plasma NEFA level was $540 \pm 85$ $\mu \mathrm{mol} / 1$ and declined progressively, falling to 419 $\pm 53 \mu \mathrm{mol} / \mathrm{l}$ after the end of the infusion. The mean fasting plasma glucagon level was $128 \pm 38 \mathrm{pg} / \mathrm{ml}$; it rose to a maximum level $(549 \pm 64 \mathrm{pg} / \mathrm{ml})$ at the end of the infusion period and began to fall when the infusion was stopped. Total glucagon secretion, evaluated by summing the increases in plasma glucagon observed during the arginine infusion was 1553 $\pm 134 \mathrm{pg} / \mathrm{ml}$.

Results of the glucose tolerance test are illustrated in Figures 2 and 3. Fasting blood glucose was $168 \pm 26 \mathrm{mg} / 100 \mathrm{ml}$ and rose to a maximum level of $386 \pm 43 \mathrm{mg} / 100 \mathrm{ml}$ two hours after the ingestion of the glucose load; afterwards it decreased progressively. Fasting plasma NEFA level was 497 $\pm 80 \mu \mathrm{mol} / 1$ and declined to a minimum value of $250 \pm 25 \mu \mathrm{mol} / 1$ at the 150 th minute after the administration of the glucose load; it increased afterwards. The effect of the oral glucose load upon plasma glucagon level was not similar in the eight patients, as shown in Figure 3 where individual values are recorded; in six patients out of the eight no systematic variation was observed; in the two remaining patients a transient increase in plasma glucagon level was observed at the 30 th or 60 th minute (cases 1 and 6).

In the eight patients all liver-function tests yielded normal results; bromsulphtalein retention was below 4 per cent at the 45 th minute and plasma creatinine level was below $10 \mathrm{mg} / \mathrm{l}$.

\section{Discussion}

In the eight patients with I. H. in this series an increase in plasma glucagon level was observed in response to arginine infusion and no decrease was noted following $100 \mathrm{~g}$ oral glucose load.

In patients with cirrhosis an abnormally high 


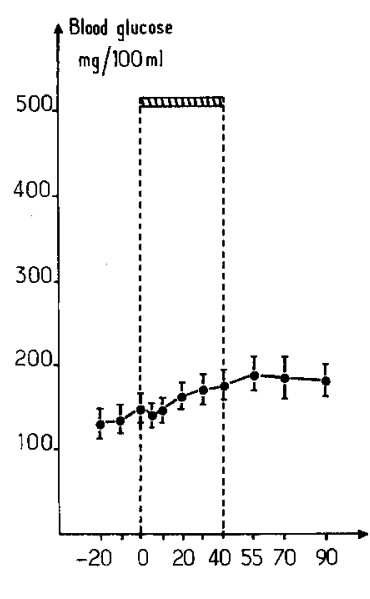

arginine intusion
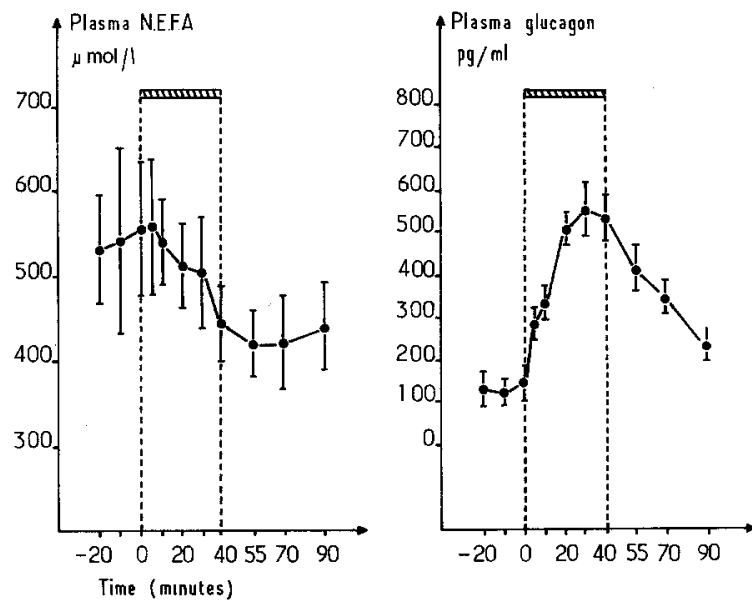

Fig. 1. Blood glucose, plasma NEFA and glucagon levels during arginine infusion in eight diabetic patients with I. H. (mean \pm SEM)

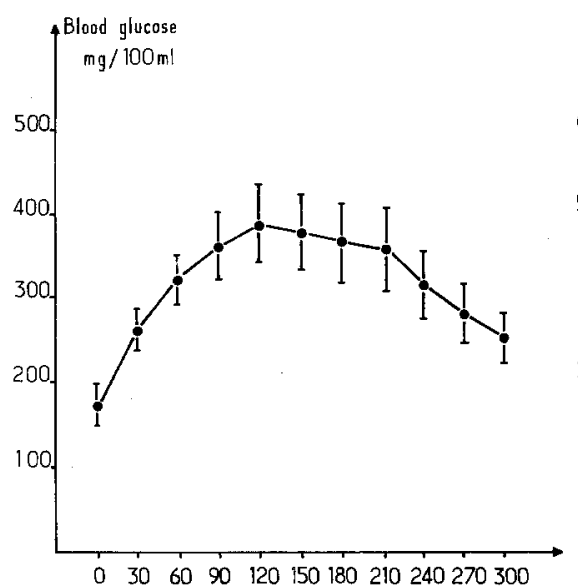

Time (minutes)

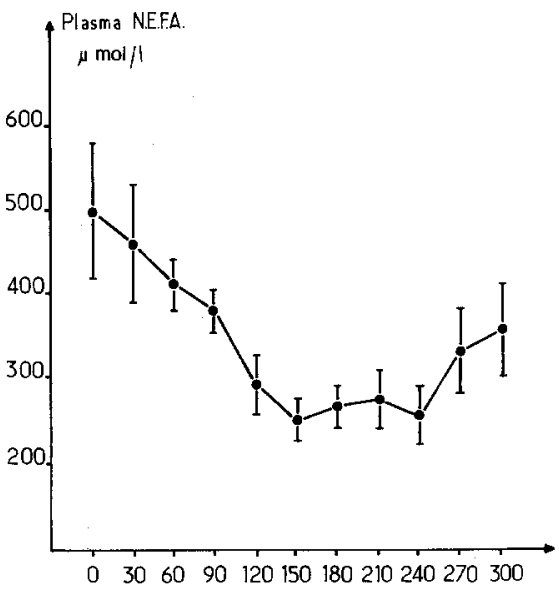

$0 \quad 3060 \quad 90120150 \quad 180210240270300$
Fig. 2. Blood glucose and plasma NEFA level following oral glucose load in eight diabetic patients with $I$. H. (mean \pm SEM)

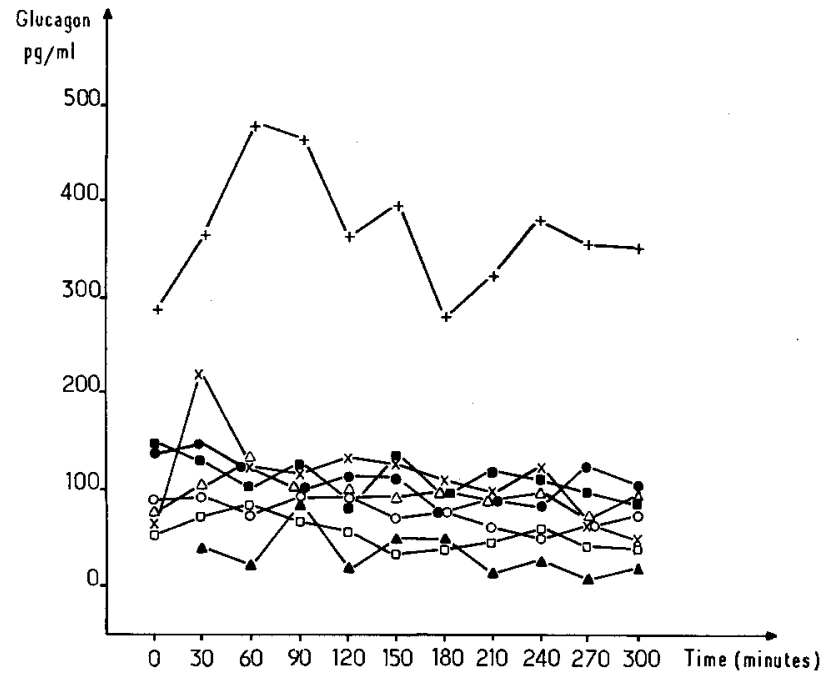

Fig. 3. Plasma glucagon level following oral glucose load in eight diabetic patients with $\mathrm{I}$. $\mathrm{H}$. plasma glucagon rise after arginine or alanine infusion has been reported $[20,21]$; however, in the patients of this study, despite the liver enlargement which is usual in haemochromatosis, no impairment of liver function was noticeable using conventional liver function tests.

In this series of patients with diabetes and I.H., the basal plasma glucagon concentration was higher than that found in normal subjects and in cases of idiopathic diabetes; however, the difference was not statistically significant. As illustrated by Table 2, the arginine-induced glucagon rise was of similar magnitude when compared with the data obtained in eleven patients with idiopathic diabetes and significantly higher than the response of normal controls [22]. In both types of patients, the excessiye glucagon responses could be secondary to insulin lack $[11,14]$. These results are at variance from those reported in diabetes secondary to pancreatic injury. 
Table 2. Comparison of the glucagon response to arginine infusion in normal subjects $\mathrm{a}^{\mathrm{a}}$, in patients with "idiopathic diabetes"a and in patients with diabetes and I. H.

\begin{tabular}{|c|c|c|c|}
\hline & $\begin{array}{l}\text { Normal } \\
\text { controls } \\
\mathrm{n}=6\end{array}$ & $\begin{array}{l}\text { Patients with } \\
\text { idiopathic } \\
\text { diabetes } \\
\mathrm{n}=11\end{array}$ & $\begin{array}{l}\text { Patients with } \\
\text { idiopathic } \\
\text { haemochromatosis } \\
n=8\end{array}$ \\
\hline Age (yrs) & $\begin{array}{l}35 \pm 5 \\
(23-55)\end{array}$ & $\begin{array}{l}59 \pm 4 \\
33-76)\end{array}$ & $\begin{array}{l}53 \pm 4 \\
(38-68)\end{array}$ \\
\hline $\begin{array}{l}\text { Weight ( } \% \text { ideal } \\
\text { body weight) }\end{array}$ & $\begin{array}{l}105 \pm 2 \\
(97-108)\end{array}$ & $\begin{array}{l}133 \pm 8 \\
94-173)\end{array}$ & $\begin{array}{l}103 \pm 4 \\
(91-130)\end{array}$ \\
\hline $\begin{array}{l}\text { Basal plasma } \\
\text { glucagon level } \\
\text { pg/ml }\end{array}$ & $58 \pm 13$ & $82 \pm 14$ & $129 \pm 38$ \\
\hline $\begin{array}{l}\text { Peak glucagon value } \\
\text { after } 40 \text { min } \\
\text { arginine infusion } \\
\mathrm{pg} / \mathrm{ml}\end{array}$ & $356 \pm 56$ & $569 \pm 136$ & $549^{b} \pm 65$ \\
\hline
\end{tabular}

Results are expressed as mean \pm SEM (range)

a These results are taken from a previous work done in identical conditions (see ref. 22)

$b$ Value significantly higher $(\mathrm{p}<0.05)$ versus that found in controls and similar to that found in the group with "idiopathic diabetes"

In pancreatectomised patients $[13,14]$, in patients having undergone partial pancreatectomy [10] and patients with chronic pancreatitis $[10,12]$ a decreased plasma glucagon response to amino acids (arginine and alanine) has been found. However, it must be mentioned that in the series of 14 patients with chronic pancreatitis reported by Kalk et al. [11], six subjects exhibited a normal (or only slightly reduced) response to arginine, a finding attributed by these authors to an almost complete insulin deficiency, while the eight others had both moderately decreased glucagon and insulin responses.

In 11 patients with I. H., Assan and Tiengo [10] reported that the arginine-induced glucagon rise was similar to the one observed in normal subjects, but slightly less than the one found in patients with idiopathic diabetes. It has to be mentioned, however, that these data were obtained using an antiserum cross-reacting with enteroglucagon and, therefore, may not reflect true changes in $\alpha_{2}$ cell function. On the contrary, the other studies mentioned above [11-14] were obtained using either antiserum $3 \mathrm{OK}$ $[12,13]$ or other pancreatic GLI-specific antibodies $[11,14]$ and can therefore be directly compared with our results.

The absence of reduction in plasma glucagon level following the oral glucose load in the patients of this study was similar to that previously reported by one of us in patients with idiopathic diabetes, using an identical glucose load in the same conditions [15], and to that observed by Heding and Ras- mussen [25]. In two out of the eight patients of this series a paradoxical rise in plasma glucagon level was noted at the 30th or 60th minute of the test; such a rise has already been reported in severe insulin-dependent diabetics [15]. In one of the patients of this series with evidence of pancreatic calcification (case $n^{\circ} 6$ ), a remarkably high basal plasma glucagon level $(384 \mathrm{pg} / \mathrm{ml})$ was observed.

Glucose intolerance and overt diabetes in I. H. are usually considered as secondary to pancreatic fibrosis due to iron deposits. Evidence supporting this concept is: 1) the high incidence of glucose intolerance or overt diabetes in I. H. $[3,7] ; 2)$ the decrease in insulin requirements in some patients following iron removal by phlebotomy [26]; 3) some special features unusual in idiopathic diabetes that is insulin-resistant $[1,7]$ and less predisposition to development of macro- and microangiopathy [27, 28].

This concept has been challenged in recent years [5] because of: 1) a high incidence of diabetes in family members of patients with I.H. with normal iron stores, 2) a poor correlation between the degree of iron overload and the presence of diabetes, 3 ) the variable effect of iron removal on glucose tolerance in family members with iron excess and diabetes, 4) the later appearance of glucose intolerance in otherwise normal family members depleted of the iron excess, and 5) the not infrequent development of microangiopathy [29-31].

Glucagon hypersecretion observed in the patients of this study in response to arginine infusion or to an oral glucose load support the view that diabetes occurring in $I$. H. is in this respect similar to the usual inherited type. However these results cannot fully support the view that diabetes occurring in I. H. is similar to the usual inherited type for it has been shown that in haemochromatotic pancreases nearly every beta cell contains iron pigment, while no pigment is demonstrable in a single recognizable alpha cell [32].

Acknowledgements. We wish to thank Dr. M. Zygelman for helpful technical assistance.

\section{References}

1. Marble, A., Bailey, C. C.: Haemochromatosis. Am. J. Med. 11, 590-599 (1951)

2. Peterson, R.E.: The metabolic basis of inherited diseases, p. 839 . New-York: MacGraw Hill 1960

3. Bothwell, T.H., Finch, C. A.: Iron metabolism, p. 393. 366 Boston: Little, Brown and Co. 1962

4. Derot, M.: Conclusions, XXXIV Congr. Franc. Med., p. 453. Paris: Masson 1963 
5. Balcerzak, S.P., Mintz, D.H., Westerman, M.P.: Diabetes mellitus and idiopathic haemochromatosis. Am. J. Med. Sci. 255, 53-62 (1968)

6. Saddi, R., Feingold, J.: Hémochromatose idiopathique et diabète. Rev. Fr. Et. Clin. Biol. 14, 252-259 (1969)

7. Dymock, I. W., Cassar, J., Pyke, D. A., Oakley, W.G., Williams, R.: Observations on the pathogenesis, complications and treatment of diabetes in 115 cases of haemochromatosis. Am. J. Med. 52, 203-210 (1972)

8. Aguilar-Parada, E., Eisentraut, A.M., Unger, R.H.: Pancreatic glucagon secretion in normal and diabetic subjects. Am. J. Med. Sci. 257, 415-419 (1969)

9. Unger, R. H., Aguilar-Parada, E., Muller, W. A., Eisentraut, A. M.: Studies of pancreatic alpha cell function in normal and diabetic subjects. J. Clin. Invest. 49, 837-848 (1970)

10. Assan, R., Tiengo, A.: Comparaison des sécrétions de glucagon dans les diabètes sucrés avec ou sans pancréatopathie acquise. Pathol. Biol. (Paris) 21, 17-25 (1973)

11. Kalk, W. J., Vinik, A.I., Bank, S., Buchanan, K.D., Keller, P., Jackson, W.P.U.: Glucagon responses to arginine in chronic pancreatitis. Possible significance in diabetes. Diabetes 23, 257-263 (1974)

12. Donowitz, M., Hendler, R., Spiro, H. M., Binder, H. J., Felig, P.: Glucagon secretion in acute and chronic pancreatitis. Ann. Intern. Med. 83, 778-781 (1975)

13. Muller, W.A., Brennan, M.F., Tan, M.H., Aoki, T.T.: Studies of glucagon secretion in pancreatectomised patients. Diabetes 23, 512-516 (1974)

14. Barnes, A.J., Bloom, S. R.: Pancreatectomised man: a model for diabetes without glucagon. Lancet 1976 I, 219-221

15. Luyckx, A.: Sécrétion de l'insuline et du glucagon. Etude clinique et expérimentale, p. 263. Paris: Masson 1974

16. Persson, I., Gytelberg, F., Heding, L. G., Boss-Nielsen, J.: Pancreatic glucagon-like immunoreactivity after intravenous insulin in normal and chronic pancreatitis patients. Acta Endocrinol. (Kbh.) 67, 401-404 (1971)

17. Hultman, E.: Rapid specific method for determination of aldosaccharides in body fluids. Nature 183, 784-787 (1959)

18. Dole, U.P., Meinertz, H.: Microdetermination of long chain fatty acids in plasma and tissues. J. Biol. Chem. 235, 2595-2599 (1960)

19. Luyckx, A.: Immunoassay for glucagon. In: P.J. Lefebvre, R.H. Unger (Eds.): Glucagon. Molecular physiology. Clinical and therapeutic implications, p. 285. Oxford: Pergamon Press 1972

20. Marco, J., Diego, J., Villanueva, M. L., Diaz-Fierros, M., Valverde, I., Segovia, J.M.: Elevated plasma glucagon levels in cirrhosis of the liver. N. Engl. J. Med. 289, 1107-1111 (1973)

21. Sherwin, R., Joshi, P., Hendler, R., Felig, P., Conn, H. O.: Hyperglucagonemia in Laennec's cirrhosis. The role of portal systemic shunting. N. Engl. J. Med. 290, 239-242 (1974)

22. Carpentier, J. L., Luyckx, A. S., Lefebvre, P. J.: Influence of metformin on arginine-induced glucagon secretion in human diabetes. Diab. Metab. 1, 23-28 (1975)

23. Ohneda, A., Aguilar-Parada, E., Eisentraut, E., Unger, R.H.: Control of pancreatic glucagon secretion by glucose. Diabetes 18, 1-10 (1969)

24. Buchanan, K.D., McCarrol, A. M.: Abnormalities of glucagon metabolism in untreated diabetes mellitus. Lancet 1972 II, 1394-1395

25. Heding, L.G., Rasmussen, S.M.: Determination of pancreatic and gut glucagon-like immunoreactivity (GLI) in normal and diabetic subjects. Diabetologia 8, 408-411 (1972)

26. Crosby, W.H.: Treatment of haemochromatosis by energetic phlebotomy. Br. J. Haematol. 4, 82-88 (1958)

27. Lonergan, P., Robbins, S.L.: Absence of intercapillary glomerulosclerosis in the diabetic patient with haemochromatosis. N. Engl. J. Med. 260, 367-370 (1959)

28. Pirart, J., Barbier, P.: Effet protecteur de l'hémochromatose vis à vis des lésions vasculaires séniles ou diabétiques. Diabetologia 7, 227-236 (1971)

29. Becker, D., Miller, M.: Presence of diabetic glomerulosclerosis in patients with haemochromatosis. N. Engl. J. Med. 263, 367-373 (1960)

30. Griffiths, J.D., Dymock, I. W., Davies, E. W. G., Hill, D. W., Williams, R.: Occurrence and prevalence of diabetic retinopathy in haemochromatosis. Diabetes 20, 766-770 (1971)

31. Passa, Ph., Rousselie, F., Ganvillé, C., Canivet, J.: Retinopathy and plasma growth hormone levels in idiopathic hemochromatosis with diabetes. Diabetes 26, 113-120 (1977)

32. Hartroft, W.S.: Islet pathology in diabetes. Diabetes 5 , 98-104 (1956)

Received: January 7, 1977, and in revised form: May 15, 1977

Prof. J. Canivet

Department of Metabolism

and Endocrinology

Hôpital Saint Louis

2, place du Dr. A. Fournier

F-75475 Paris Cedex 10

France 